Abstracta Iranica Abstracta Iranica

Revue bibliographique pour le domaine irano-aryen

Volume 42-43 | 2021

Comptes rendus des publications de 2019-2020

Arash Zeini. Zoroastrian scholasticism in Late
Antiquity. The Pahlavi version of the Yasna Haptaghaiti

Benedikt Peschl

(2) OpenEdition

1 Journals

Electronic version

URL: https://journals.openedition.org/abstractairanica/53025

DOI: 10.4000/abstractairanica.53025

ISSN: 1961-960X

Publisher:

CNRS (UMR 7528 Mondes iraniens et indiens), Éditions de l'IFRI

Electronic reference

Benedikt Peschl, "Arash Zeini. Zoroastrian scholasticism in Late Antiquity. The Pahlavi version of the Yasna Haptanhāiti", Abstracta Iranica [Online], Volume 42-43 | 2021, document 5, Online since 30 December 2021, connection on 13 December 2022. URL: http://journals.openedition.org/abstractairanica/53025 ; DOI: https://doi.org/10.4000/abstractairanica.53025

This text was automatically generated on 13 December 2022.

All rights reserved 


\title{
Arash Zeini. Zoroastrian scholasticism in Late Antiquity. The Pahlavi version of the Yasna Haptayhāiti
}

\author{
Benedikt Peschl
}

\section{REFERENCES}

Arash Zeini. Zoroastrian scholasticism in Late Antiquity. The Pahlavi version of the Yasna Haptayhāiti. Edinburgh, Edinburgh University Press, 2020, xxviii + 401 p. (Edinburgh Studies in Ancient Persia).

1 This book, which is ultimately based on the author's doctoral dissertation, provides a rich study of the Pahlavi version ('Zand') of the Yasna Haptayhāiti (YH), one of the two integral parts of the Old Avesta (the other being the Gāthās). Proceeding from a variorum edition of the Pahlavi text, accompanied by a translation and miscellaneous commentaries, the book includes several thought-provoking essays. These cover topics such as the nature and internal structure of the Zand, its position in the history of Zoroastrian exegesis, its close inter-textual interdependence with non-Zand Pahlavi literature, and aspects of Sasanian Zoroastrian theological thought. As indicated by the title, a notion that sets the tone for the book is the treatment of the Zand against the background of 'scholasticism' as a general phenomenon of the late antique mind.

2 The book is divided into four parts. The 'Introduction' (Part I) first gives an overview of the Avestan and Pahlavi YH, of the principles underlying the author's new edition of the Pahlavi text, as well as of the nine manuscripts used for the edition and their mutual relations. Most importantly, the author has used the comparatively late, but excellent ms. 400_Pt4 (ca. $1780 \mathrm{CE}$ ) as a base text against which deviations found in other manuscripts are treated as alternatives, without necessarily implying one reading to be more original than the other ('variorum edition'). This approach reflects 
the author's questioning of 'whether stratified texts [such as the Zand] can at all be revised to a presumed lost original' (p. 10).

Within Part I, the introduction to the edition is followed by three interrelated essays (sections 2-4). Section 2 ('The Zand') discusses the Pahlavi version of the Avesta in broad terms, with a focus on its scholarly reception through past decades. In section 3 ('Scholasticism'), the author outlines his own innovative approach to the Zand, based on a theory of scholasticism proposed by Cabezón (José Ignacio Cabezón. Scholasticism. Cross-cultural and comparative perspectives. Albany NY: State University of New York Press, 1998). As Zeini shows, the neat way in which Cabezón's defining features of scholasticism can be applied to the Zand allows us to regard this body of material as the expression of a 'scholastic' approach to the Avestan texts on the part of their Sasanian exegetes. Section 4 ('Fire in Zoroastrianism') exemplifies the philologist's task of disentangling the Zand's excessive intertextuality (one of its scholastic features) in order to arrive at a full picture of the exegetes' views on a given subject.

4 Part II contains the newly established text of the Pahlavi YH (in transcription) together with an English translation. The text-critical edition (in transliteration) and apparatus are included in an appendix. This edition of the Pahlavi YH must be considered the new reference point for any future work involving the text. A distinctive feature of Zeini's presentation of the constituted text results from his decision not to follow the common practice of visually dividing the Zand into a translation layer (consisting of a roughly word-by-word translation of the Avestan text) and a commentary layer (consisting of explanatory comments added to the translation).

5 Part III ('Miscellaneous Observations') consists of a selection of commentaries on individual passages of the Pahlavi YH. These range from short notes to small essays, addressing, for example, the meaning of rare words, issues of translation technique, and religious themes and notions mentioned or alluded to in the text. Since the discussions refer to a wide range of related passages in the wider realm of Pahlavi literature, the book will be essential to consult not only for those working on other parts of the Zand, but also those engaged with Pahlavi literature in general.

6 Taking up the discussion in Section I.2, the important Part IV ('Reflections on the Zand') offers the author's concluding considerations on the compositional structure of the Zand. Among other points, Zeini defines the text as having received its current shape in a setting of written literarity while still reflecting signs of its origin from an oral exegetical tradition ('residual orality').

\section{AUTHORS}

\section{BENEDIKT PESCHL}

Université de Bochum 